\title{
COVID-19 Stigma and Charismatic Social Relationship: A Legitimization Narrative of President Trump's Status as a Charismatic Leader following a SARS-CoV-2 Infection Reported by the Portuguese Media
}

\author{
Carlos Miguel Ferreira ${ }^{1, *}$ and Sandro Serpa ${ }^{2}$ (D) \\ 1 Interdisciplinary Centre of Social Sciences-CICS.NOVA, Estoril Higher Institute for Tourism and Hotel \\ Studies, 2765-273 Estoril, Portugal \\ 2 Interdisciplinary Centre for Childhood and Adolescence-NICA-UAc, Interdisciplinary Centre of Social \\ Sciences-CICS.UAc/CICS.NOVA.UAc, Department of Sociology, Faculty of Social and Human Sciences, \\ University of the Azores, 9500-321 Ponta Delgada, Portugal; sandro.nf.serpa@uac.pt \\ * Correspondence: carlos.ferreira@eshte.pt
}

check for updates

Citation: Miguel Ferreira, C.; Serpa, S. COVID-19 Stigma and Charismatic Social Relationship: A Legitimization Narrative of President Trump's Status as a Charismatic Leader following a SARS-CoV-2 Infection Reported by the Portuguese Media. Societies 2021, 11, 130. https://doi.org/10.3390/ soc11040130

Academic Editor: Gregor Wolbring

Received: 15 September 2021

Accepted: 22 October 2021

Published: 28 October 2021

Publisher's Note: MDPI stays neutral with regard to jurisdictional claims in published maps and institutional affiliations.

Copyright: (c) 2021 by the authors. Licensee MDPI, Basel, Switzerland. This article is an open access article distributed under the terms and conditions of the Creative Commons Attribution (CC BY) license (https:// creativecommons.org/licenses/by/ $4.0 /)$.

\begin{abstract}
This concept paper aimed to understand how stigma, a concept usually associated with negative social relationships, in the context of a pandemic threat such as COVID-19 can, in some situations, structure a charismatic social relationship in a perceived positive association between stigma and a specific social characteristic. For this purpose, we used the example of the news selected and highlighted by several Portuguese media about the actions and messages developed by President Trump in the context of his infection with SARS-CoV-2 and the subsequent recovery process. These news reports gave visibility to a narrative that can be considered as reinforcing the legitimization of his condition as a charismatic leader in an electoral context marked by the pandemic threat. In conclusion, stigma associated with a pandemic health threat and generally linked to a negative social status can also reinforce admiration, trust, and belief in the charismatic leader by supporters and followers, as demonstrated with the plight of President Trump. Stigma can be a factor in social uplift in affirming an upward trajectory of social status and symbolic power for actors seen as ill, where stigma-motivated discrimination is experienced positively, unlike in most cases.
\end{abstract}

Keywords: COVID-19 pandemic; SARS-CoV-2; stigma; stigmatization; charisma; charismatic domination; President Trump; legitimation; social elevation; media narrative; media

\section{Introduction}

This conceptual paper aimed to understand how stigma, a concept usually associated with a negative social relationship, in the context of a pandemic threat such as COVID-19 can, in some situations, structure a charismatic social relationship in an association between stigma and a socially positive dimension. For this purpose, the authors analyzed selected news stories highlighted by several Portuguese media about the actions and messages developed by President Trump in the context of his infection with SARS-CoV-2 and the subsequent recovery process. These news items give visibility to a narrative that can be considered as reinforcing the legitimization of his condition as supreme leader in an electoral context marked by the pandemic threat [1].

The perception of this condition of a supreme chief is based on a gift, i.e., on the extraordinary ability that chiefs possess. These exceptional gifts gain visibility and meaning in the proclamation and realization of a political, warlike, religious, or philanthropic objective, among others [2]. Those who acknowledge this gift also acknowledge the duty to follow the charismatic leader, whom they obey exclusively because of their exceptional qualities and not according to their statutory position or traditional dignity [3]. The 
influence of charisma is born and persists if the goal is achieved, i.e., if it offers effective and useful evidence capable of strengthening the faith of the followers [2].

Charisma cannot be confused with prestige, consideration, popularity, or personal talent. Charisma establishes a social relationship that fundamentally changes the structure of behavior [4]. Charisma produces its "magic from within"; "charisma produces a transfiguration of identity" [5] (p. 67).

Charisma as an unpredictable, revolutionary force presents a disruptive capacity for all established orders [3,5]. A charismatic situation creates a rupture with the usual and institutionalized structures of behavior. A charismatic leader is not just a person who inspires confidence, raises high expectations, or to whom special competencies are ascribed. A charismatic leader establishes a new leadership position, a new structure of social relationships, and a new cognitive definition of the action situation [4] (p. 5).

In this relationship between stigma and charisma, and despite considering stigma as a mark or trait that devalues the individual [6], emphasizing the negative effects that it can cause on individuals, stigma can be seen as the mark of something extraordinary that, on the contrary, enhances the affirmation of the social status and symbolic power of the actors characterized as ill-healthy (for example, COVID-19), in which labelling, stereotyping, cognitive separation, and discrimination [7] tend to transform significantly, reinforcing the admiration, trust, and belief in the chief by supporters and followers.

\section{The COVID-19 Pandemic and the Stigmatization of the "Other"}

The COVID-19 pandemic, like any other pandemic, is a health threat that can be characterized by uncertainty, powerlessness, dystopia, and fear of the "other" [8]. The belief in the association between contagion and danger intrinsic to the health threat caused by COVID-19 has reinforced fears, prejudices, stigma, and xenophobia, reproducing a social image of the dangerousness of the disease, the "impure" patients, the potential patients, and the regions and countries associated with the genesis of the disease. The epidemic is categorized as an attribute inherent in the invasion of the "strange", the "foreign", the "other".

COVID-19 shaped a stigma generally understood as full social disqualification, in negative discrimination that generates exclusion [9-16].

The WHO (World Health Organization) [17] stated that three core factors underpin the level of stigma arising from COVID-19: “[...] (1) it is a disease that's new and for which there are still many unknowns; (2) we are often afraid of the unknown; and (3) it is easy to associate that fear with 'others'. It is understandable that there is confusion, anxiety, and fear among the public. Unfortunately, these factors are also fueling harmful stereotypes" (p. 1).

Stigma corresponds to a mark or attribute that devalues the individual [6]. According to Goffman [6], identity manipulation may occur in the relationship with others through social information and full social acceptance- or not—based either on discredited attributes (visible or known) or discreditable attributes (attributes that may become known). Stigma is a mark or attribute that links the individual to undesirable characteristics, the stereotype. Thus, stigma can affect individuals directly, through mechanisms of discrimination and automatic activation of the stereotype, and indirectly, to the extent that it can threaten the personal and social identity of the stigmatized individual [18].

COVID-19, as a contagious disease, seems obviously undesirable for everyone, so its classification as a disease seems objective and self-evident. However, it is a social assessment. Although this assessment focuses on the "disease", it imposes on the "sick" person to wish to be cured and seek technically competent help. Otherwise, the individual would be freed from other roles and would not be responsible for their actions. The nosological classification and social qualification of a given "disease" is not a socially neutral process; medical management is characterized by the close articulation between legitimacy and stigma. To consider someone as sick has immediate consequences for their identity, and the medical qualification of a disease, even if it is a mistake, may be 
sufficient to introduce the individual into a career of sickness. Even if the illness has seen its legitimacy recognized-having the right to be sick— the sick person cannot always avoid stigmatization [19].

Stigmatization can be seen as a social process within a power relationship. Besides emphasizing the interdependent relationships between "normal" and "stigmatized", this conceptualization allows this social phenomenon to be placed within a dynamic social, cultural, economic, and political context. The process of stigmatization occurs when labelling, stereotyping, cognitive separation, loss of status, and discrimination are interrelated in a situation of power that allows such components to happen [7]. Power can be seen as conducive to the process. Dominant groups have the ability to impose their values, norms, and beliefs on people with fewer resources; stigmatization is a condition that promotes inequality regarding the distributions of resources and power in a given society and time, enabling the categorization and labelling of differences, the construction of stereotypes, the separation between the "normal" and the "others", disapproval, rejection, exclusion, and discrimination [7].

This social process of stigmatization is characterized by several interdependent components of categorization and labelling that negatively and continuously limit the life of those who are victims of this process, such as labelling, stereotyping, physical and/or social separation, status loss, discrimination, and exclusion by those considered in a given social and cultural context normal or dominant in relation to others $[6,7]$.

The mobilization of this conceptual perspective allows framing an analytical model for understanding the social process of stigmatization associated with a disease in which negative social representations emerge and are reinforced for certain groups of individuals $[20,21]$. This model has the following characteristics: the disease that is the object of stigmatization is conceived as avoidable and considered to be under the control of those affected; the behavior that caused the disease or the condition considered to be a risk of a disease is the object of some form of disapproval, a moral judgement is performed on people, and they are blamed for the disease or the behavior; the individuals or groups affected by a given disease are associated with negative stereotypes (negative social representations associated with the disease); people are associated with a socially differentiated group, i.e., a labelled and stereotyped group with which a distancing is made based on the existing social representations of the "other"; and people see their social status "diminished" and suffer various forms of disadvantage, whether the stigma is real, anticipated or perceived $[7,20,21]$.

\section{COVID-19 and the Processes of Stigmatization}

Every society has social control mechanisms to ensure that the majority of its members conform to the socially dominant norms and rules. People who do not conform to these rules or break social taboos are socially excluded [22]. For Becker and Arnold [22], members of society have common beliefs about the cultural significance of an attribute and the stigma attached to it. These beliefs about stigma dictate the nature of stigma. People take specific attitudes about a given stigma and the responses of stigmatized people, thus affecting the way in which a stigmatized individual is either integrated into a group or socially excluded [22,23].

In the various representations conveyed in multiple discursive records about COVID19 , this pandemic is associated with the matrix metaphor of the plague expressed in the series contagion-death-medi-isolation. The contagion-epidemic dyad underlies the perception of a great danger, amplified in contemporary societies by the extreme speed of movement of people, goods, and information. The belief in the association between contagion and danger intrinsic to epidemic diseases, namely the COVID-19 health threat, has reinforced fears, prejudices, and enhanced stigma and xenophobia, reproducing a social image of the dangerousness of the disease, the "impure" patients, the potential patients, and the regions and countries associated with the genesis of the disease. 
Negative social representations associated with epidemics and contagions have persisted over time, reinforcing prejudices and potentiating the stigmatization processes of various groups of individuals and some regions. Hostile attitudes have been and continue to be directed at groups categorized and socially labelled as having negative attributes in relation to the dominant groups in certain contexts: the familia diaboli [24]—consisting of beggars, vagabonds, Jews, "lepers", prostitutes, gravediggers-in the plague epidemic in the 14th century; the vagabonds and the destitute in the Renaissance in the epidemics of black plague and typhus; Irish immigrants in the cholera epidemic in the 19th century; the poor and working classes-the "dangerous classes"-in the outbreaks of tuberculosis in the 19th and 20th centuries; homosexuals, Haitians, hemophiliacs, and heroin addicts in the 1980s in the HIV / AIDS epidemic; the indigenous people of the European colonies in the 19th century associated with the resurgence of leprosy; Africans linked with the emergence of the "West Nile Virus", the "Lassa Fever", the "Ebola Virus"; and Chinese and Asians in the H1N1, H5N1, SARS, and COVID-19 epidemics [25].

The stigma generated by COVID-19 is usually a source of shame, anxiety, and potentially social rejection felt directly by the infected, stigmatized person (or the person considered by others as a possible agent of infection) but also by those close to them (family, friends, health professionals, and communities considered to be more conducive to the existence and transmission of the virus, among others) $[15,26-28]$. Stigma is almost always regarded for its potentially negative characteristics of social rejection and the various consequences involved, and the same has happened with its association with COVID-19 [11,29-41], which may even reinforce pre-existing stereotypes, difficulties, and negative images [33,42]. According to Joshi and Swarnakar [36] (p. 3), "All these cases of infectious-disease stigma rely on a binary between the 'normal' and the 'other' in the form of a culturally defined negative attribute or stigma to pass blame through social positions of power and control".

The stigma arising from COVID-19 has, therefore, an important effect on three dimensions of the infected individuals' lives: (1) individual life and well-being: this stigma reduces the individuals' opportunities, negatively affects their ability to prevent and control health risks, causes the violation of human rights and dignity, increases physical and psychological stress, and in many cases leads to self-stigma; (2) public health and pandemic response: stigma hinders the detection and control of the disease, impacts health professionals, and contributes to increased mortality and morbidity; and (3) society at large: the COVID-19 stigma causes increased social inequalities, notably through the marginalization of those infected and the normalization of exclusion [43]. Table 1 shows how stigma manifests in behaviors and its consequences on individuals.

Table 1. How stigma occurs and what impacts it has.

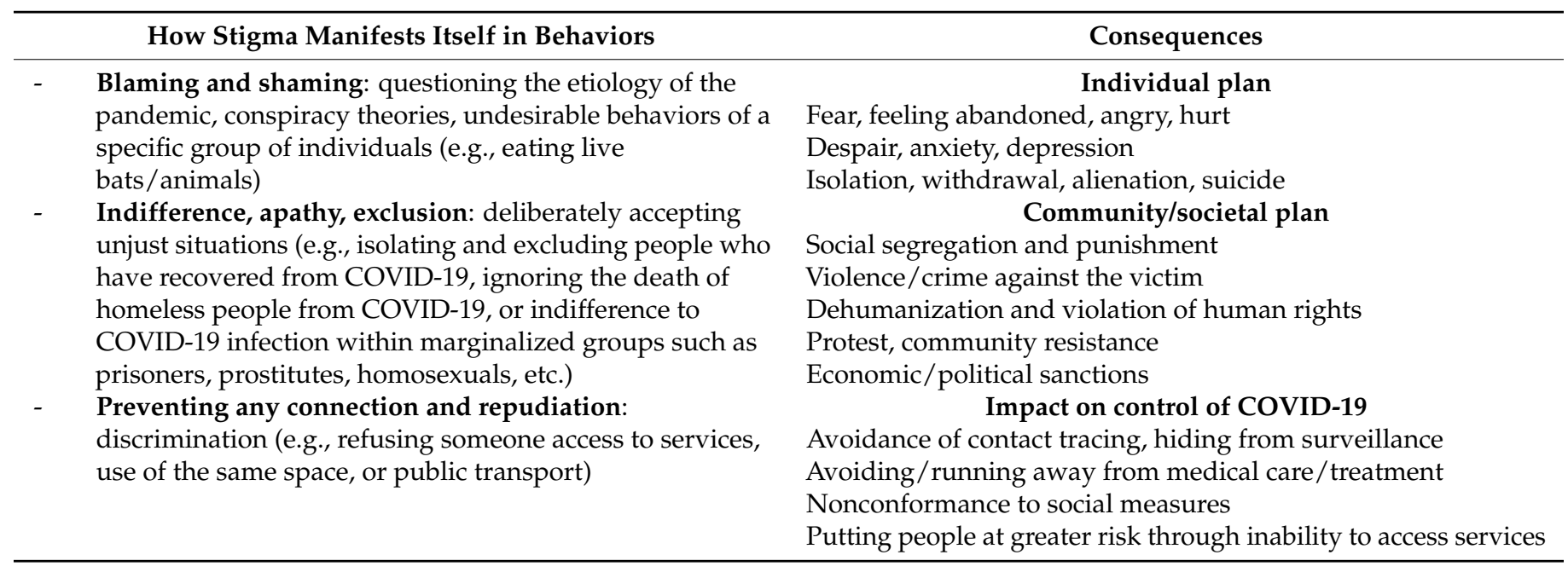


Table 1. Cont

\begin{tabular}{|c|c|c|}
\hline & How Stigma Manifests Itself in Behaviors & Consequences \\
\hline- & $\begin{array}{l}\text { Denying access: to employment, education, health } \\
\text { services, or housing (expulsion of the person from their } \\
\text { home or removal from schools) } \\
\text { Verbal attacks, threats, harassment, pointing and } \\
\text { offending: ethnocentrism, prejudice, degrading } \\
\text { comments or looks, cursing, shouting } \\
\text { Victimization and violence: physical assaults }\end{array}$ & $\begin{array}{l}\text { The impact on health workers further weakens the health } \\
\text { system and the ability to control the pandemic }\end{array}$ \\
\hline
\end{tabular}

Source: WHO [44] (p. 6).

In summary, individuals infected with or considered to be infected with COVID-19 are often seen as active agents of virus dissemination. This stereotypical view leads society to treat these individuals negatively [15]. In the current pandemic situation, one aspect of the salutogenic discourse focuses on the metaphor of body contamination, intensifying the susceptibility and aversion to body degradation. The sick, the old, the contaminated, and those with bodily marks of physical decay tend to be excluded or ignored [45]. Nuckchady [34] (p. 32) presents a categorization of infected individuals, and thus potential victims of stigmatization, into the following four groups: "[...] stigma of people who are perceived to be carriers of the disease but who most likely are not infected, stigma of people who are actually infected, stigma of people who were infected but who have recovered and are no longer contagious and stigma towards people who care for the ill".

\subsection{Stigma and Charismatic Domination}

In almost all of the consulted studies that analyzed, directly or indirectly, the COVID19 pandemic and its social consequences, stigma and the process of stigmatization were addressed in a socially negative way; i.e., the studies focused on the negative impacts of stigma on the lives of people socially categorized as stigmatized $[6,17,26,27,33,46,47]$. Despite the negative effects that stigma can cause in individuals, stigma can be seen as the mark of something extraordinary that, on the contrary, promotes the affirmation of the social status and symbolic power of the actors characterized as ill-healthy, in which the labelling, stereotyping, cognitive separation, and discrimination [7] tend to be significantly transformed, reinforcing the admiration, trust, and belief in the charismatic leader by supporters and followers. The indispensable presupposition is "to be believed": the charismatic leader has to be believed as a leader "by the grace of God" [3].

In the analysis of the configuration of the charismatic social relationship, the model of charismatic domination proposed by Max Weber was favored. The Weberian model offered the advantage of thematizing the issue of the relationship between the person and the structure [4].

In this model, domination is viewed as a structure of power that not only demands obedience, but demands obedience resulting from the will to obey [5]. Domination, as a probability of finding obedience to a particular mandate, can be based on various motives of submission [3]. The kinds of pretension that the holders of power have for the legitimacy of their power shape the forms or types of domination: traditional, charismatic, and rational-legal. Traditional domination is based on the appeal to the sanctity of habits and immemorial traditions; rational-legal domination is based on formally approved rules and statutes and has its archetype in the bureaucracy; and charismatic domination is based on the personal gift of a heroic figure who is in a state of grace $[3,5]$.

In charismatic domination, individuals obey the charismatically qualified chief because of personal trust in revelation, heroism, or exemplarity within the scope of the validity of the belief in the chief's charisma [3]. Leaders that exert this type of domination are characterized by having a specifically extra quotidian character, presenting a strictly personal social relationship associated with the charismatic validity of personal qualities and their proof [3]. 
Charisma, in the Weberian sense, is understood as a quality deemed extraordinary of a person through which they are regarded as endowed with supernatural or superhuman forces or characteristics not accessible to all, or else are seen as sent by God or as exemplary and therefore as "chief" [3] (pp. 706-707). Charisma is thus based on a social relationship between a charismatic individual and a believer who is faithful to the charisma. The feature considered charismatic is ascribed to an individual by their followers; in turn, the bearer of charisma gains recognition of the charisma they claim. A social relationship is shaped in which the position of the leader, the dominance exercised, and the form of obedience have a specific nature [4]. Weber's model is not oriented towards an analysis of the personality of the charismatic leader, but towards the structure of the charismatic social relationship characterized by a set of specific features [4].

The first feature concerns the recognition of the validity of the charisma by the dominated, assured by the verification inherent in the revelation, the veneration of the hero, the trust in the chief. The chief claims supreme authority, whereas the disciple accepts obedience as a duty. The charismatic chief must be willing to claim supreme authority, and the follower must be willing to submit entirely to the chief. The second feature of a charismatic relationship regards the dissolution of previously existing norms, procedures, and forms of organization. The more a charismatic chief makes claims about themselves that they want all others to accept, the less they can allow for other normative rules and control procedures. These would limit their arbitrariness by subjecting obedience to certain conditions. The third feature is a consequence of the previous one. The social formation that is shaped based on charismatic relationships is an "emotional communization", the cohesion of which is linked to a personal bond with the chief and that, when the size of the group requires so, is organized by the disciples and trusted persons summoned by the chief. The fourth feature of a charismatic relationship is the need for confirmation. The belief in charisma, its ascription to a person, is dependent on the perception of confirmation. The expectations associated with the belief in charisma are not disconnected from the perception of reality and the interests of those who believe in it. Confirmation can be attained when the followers' propensity to believe is reinforced by "enthusiasm, distress or hope" [4] (p. 4), i.e., when the orientation of action is emotional and, when in a situation of uncertainty, alternative interpretations and options for action are lacking. Once a charismatic leadership position is established, its holder is likely to determine the perception of reality in their followers and exclude alternative courses of action, deinstitutionalizing the processes of intention and decision making [4] (p. 4).

The precondition for establishing charismatic dominance is the existence of a latent charismatic situation, a propensity to believe in charisma and to submit to direct personal dominance [4] (p. 5). This latent charismatic situation has two dimensions: one cultural and one social [4]. The cultural dimension emphasizes that the propensity for charismatic belief is culturally determined by the idea that transcendental powers directly influence human destiny and are embodied in the qualities of an individual, who acts on behalf of a God or "Providence". In American culture, there is a relatively strong tendency towards the belief in charismatic forces. The perception of a crisis underlies the social dimension of a latent charismatic situation. The inability to overcome the crisis delegitimizes national and international political institutions, which are held responsible for its genesis and development; the hope grows that a "strong individual" will emerge to put an end to the situation of distress. A latent charismatic situation emerges only when a charismatic claim is made, when an individual seems to promise to overcome the crisis and this message is deemed acceptable [4] (p. 7).

\subsection{President Trump's Legitimation Narrative of Charismatic Chieftaincy following a SARS-CoV-2 Infection Reported by the Portuguese Media}

The authors analyzed some selected news stories highlighted by several Portuguese media about the actions and messages developed by President Trump in the context of his SARS-CoV-2 infection and subsequent recovery process. These news items gave visibility to a narrative that can be considered as reinforcing the legitimization of his condition as 
supreme leader in an electoral context marked by the pandemic threat. Different types of public domain documentary sources were mobilized, namely newspapers, videos, posts, and television reports (RTP, Portuguese Public Television), on the process of the infection and recovery of President Trump.

It should be noted that public domain documents reflect two discursive practices: as a genre of circulation, as artifacts of the sense of making public; and as content, in terms of what is printed on their pages. They are "in time" products and significant components of everyday life; they complement, supplement, and compete with narrative and memory. Documents in the public domain, like records, are documents made public; their intersubjectivity is a product of interaction with an unknown but meaningful and often collective other [48].

Media can be understood as practices of meaning construction in public spaces, which enable the configuration of shared universes and guide the topics of conversation of social groups based on debates and polemics determined by the specific interests of these groups [49]. The media are relevant in the process of the social construction of reality: they guide the public's attention and influence its perception of reality as well as determining the social relevance of topics and what is under discussion in the social space.

In the news selected and reported by the Portuguese media on the infection and recovery process of President Trump, the authors focused on identifying the thematic structures of each text, which implied a reduction of the information to the central semantic aspects. This reduction was performed through "macrorules", namely the elimination of redundant information and the summary of several propositions into a single, more generic one, allowing the reconstruction of the texts in the form of "thematic skeletons" [50,51]. Macrostructures (organized sets of prepositions) as macropropositions were organized into a set of categories emphasizing the causes of an event, the antecedents, and the consequences [50,51], being relevant elements of a narrative that underlies the time sequence of an action, an outcome, characters, and a framework of action [51].

The vicissitudes of President Trump's recovery process were prolifically reported in the media. In Portugal, multiple media considered to be of high quality and reliability broadcast several reports on the recovery of President Trump in which the characteristics of a charismatic leader can be highlighted (or, at least, the transmission of several of these characteristics were present in some of the news reports) [52-54].

The Público newspaper, dated 2 October, 2020, reported that North American President Donald Trump was infected with the new coronavirus, along with first lady Melania Trump:

"The information was advanced by the head of state himself via the social network Twitter. 'Tonight, Melania and I tested positive for COVID-19. We will begin our quarantine and recovery process immediately. We will get through this together,' he wrote. Melania Trump also confirmed on Twitter that the couple is infected. 'As too many Americans have done this year, Donald Trump and I are in quarantine at home after testing positive for COVID-19. We are feeling fine and have postponed all engagements for the foreseeable future. Please make sure you are safe and we will get through this together.' The US President's physician, Sean Conley, has also confirmed this information and assured that both 'plan to stay at home inside the White House' during their convalescence, without saying, however, whether the couple has symptoms of the disease. 'The White House medical team and I will be keeping a watchful eye, and I appreciate the support provided by some of the greatest medical professionals and institutions in our country. Rest assured, I expect the President will continue to perform his duties uninterrupted during his recovery, and I will keep you informed of any future developments,' he stressed in an official statement quoted by The New York Times. At 74 years of age, Trump falls into one of the risk groups for COVID-19. According to the American daily, about eight out of ten deaths attributed to the disease in the U.S. were recorded in citizens over 65 years. In May, and despite warnings from public health authorities, the President had already stated that he was taking hydroxychloroquine (a drug used to treat malaria 
and autoimmune diseases such as rheumatoid arthritis or lupus) after two White House staffers revealed that they were infected.

The isolation that Trump will now have to comply with will condition his campaign for the November 3 presidential election, in which the Republican-backed candidate faces Democrat Joe Biden, with whom he debated on Tuesday" (Pedro Guerreiro and Sofia Neves, 2 October 2020; https: / / www.publico.pt/2020/10/02/mundo/noticia/trumptesta-positivo-covid19-entra-isolamento-plena-campanha-presidencial-1933713, accessed on 17 October 2021)

A beneficial representation of the disease underlies these messages [55]. While in the disease-bad-happiness model, individuals experience the disease as harmful, unbearable, and responsible for the loss of their credibility, in the beneficial model, symptoms are not considered as a deviation to be contained but as a message to be heard and decoded. Illness is a reaction that has, if not a value, at least a meaning, since it is seen as an attempt to restore the disturbed balance and even, in some cases, as an exalting and enriching episode. The dominant beneficial representation of illness is that of the disease-salvation, in the religious view, as a grace, holiness, that exalts, liberates, and enriches [55]. The disease is felt as "liberating" when it offers the individual the possibility of escaping from a social role perceived as suffocating and unbearable. Far from being perceived as a misfortune or destruction, illness is seen as an opportunity to find meaning in one's life, to affirm "new life norms" that lead to the individual's enrichment and fulfillment. This condition takes on a negative or positive value depending only on how the individual lives it in relation to the environment, i.e., in relation to the individual's own normative power [56]. The experiences and representations of a disease acquire meaning only through connection to the set of interdependent relationships between individuals and society present in the interpretation of the illness in a specific time and space. Thus, on the one hand, an illness expresses the living conditions, values and belief systems, medical knowledge, and representations in a given spacetime; on the other hand, an illness is "resented" by the individual only when the signs that they perceive correspond to the symptoms that are socially recognized as disease indicators [57-59].

President Donald Trump's ritualized actions, as reported in some relevant Portuguese media, embody something that goes beyond everyday normality in the sense of exalting everyday behaviors. Rituals can be both routine and excessive, transporting the people involved into a somewhat extraordinary world. These rituals can be understood as manifestos against indeterminacy $[60,61]$, as symbolic acts that aim at mitigating uncertainties and insecurities, fostering a feeling of ontological security among their adherents and followers. Every rite tends to consecrate or legitimate, i.e., make an arbitrary limit recognized as legitimate, as natural [62]. The "limit" that Bourdieu [62] mentions (p. 58) is the symbolic line marking the passage between the before and the after. It is thus the line demarcated by the rite that signals a change of state, the passage from one condition to another [62].

Rádio Televisão Portuguesa (RTP), a public television network, reported on 8 October, 2020, that President Trump, speaking of his early recovery at lines, said that contracting the COVID-19 disease had been a "blessing from God" and that he wished all Americans had "the same treatment as their President":

"[...] US President Donald Trump said that contracting COVID-19 was a 'blessing from God' and assured that it will help 'heal' other Americans, although he himself has not yet overcome the disease. 'It made me feel better, I call that healing. And I want everyone to have the same treatment as their President', Trump said in a video posted on Twitter. [...] In this regard, Trump explained that his Administration plans to approve, as a matter of urgency, the Regeneron cocktail he was administered and assured that it will be distributed free of charge" (Mário Aleixo-RTP, 8 October 2020 (https: / / www.rtp.pt/noticias / mundo/covid-19-trump-diz-que-contraira-doenca-foi-uma-bencao-de-deus_n1265044, accessed on 17 October 2021) 
The Expresso newspaper of 7 October reported that President Trump reiterated that this was indeed a cure:

"They're going to say that this is therapeutic, and maybe these medicines are really therapeutic, some people don't know how to define 'therapeutic', the views are different, but for me it's a cure. I went in, they gave me the treatment, and $24 \mathrm{~h}$ later I was perfect, I wanted to leave the hospital. I want everyone to have the same treatment as your President. It was a blessing from God. And I was the one who said I wanted to have this treatment. I want you to have the same treatment and for free. You are not to blame for this, it's China's fault, China will pay" (Expresso, 7 October 2020, https:/ / expresso.pt/coronavirus/2020-10-07-Covid. -Trump-diz-que-tratamento-que-recebeu-e-uma-cura-promete-oferece-lo-de-borlaafirma-se-abencoado-por-Deus-e-ataca-a-China, accessed on 17 October 2021)

This narrative highlighted a set of actions and messages developed by President Trump, which can be considered as reinforcing the legitimization of his charismatic leader status in an electoral context marked by the pandemic threat.

These various news stories about President Trump's infection with the new SARS coronavirus COV-2 expressed the meanings that translate the semantic network of the disease $[63,64]$, the symbolic connections that a given individual establishes among their various life experiences, particularly critical events and experiences. The meaning units composed of words used to describe symptoms and sensations are connected by causal relationships or by a metaphorical, analogical, or symbolic logic [64]. The logic inherent in the semantic network allows one to go beyond the representations underlying the etiological and therapeutic models, allowing the individual to interpret the disease within their social and cultural context [64]. Language and representations have a symbolic efficacy in constructing reality and structure the perception that social agents have of society [65].

Following the media account exposed above, one possible interpretation is that, for the American President and his supporters and followers, this miraculous nature of the President's healing expresses "the two bodies of the President": human by its nature and divine by the granting of God's grace. The "presidential miracle" is presented as the expression of the supreme political power of the "Head of State", who exercises a centralizing power of physical and symbolic force. It is the affirmation of the symbolic dimension of the President's power. This President's symbolic power is a power to consecrate or reveal things that already exist. This symbolic power is founded on the possession of symbolic capital, which is situated in the order of knowledge and recognition. The followers, the dominated, know and recognize: the act of obedience presupposes an act of knowledge, which, at the same time, is an act of recognition [65]. In the recognition, there is "knowledge"; those who submit, obey, subject themselves to an order, operate a cognitive action. The acts of submission and obedience are cognitive acts that operate cognitive structures, categories of perception, schemes of perception, and principles of vision and division [65].

We recall that the leaders based on charismatic authority, when successful in a particular action or outcome, are perceived as having high competence, to the detriment of their conventional peers who have not attained this success. Conventional leaders are considered unworthy of leadership; they possess qualities that would have made them worthy of leadership in the past but that, according to the new charismatic criteria, are a sign of their unworthiness as leaders. That is, "[...] just as the charismatic leader impresses the onlooker by means of a positive expression of their new vision and mission, so the conventional contender performs the inadequacy of the status quo" [53] (p. 930).

The expression of the charismatic process, the new rules, the force, the proofs that demonstrate the legitimacy of the charisma and the mission, are placed in a revolutionary way in relation to the institutionalized situation through a social experience that demands conversion (metanoia) in the followers' attitudes and behavior, as in those of the leader themselves. The reference to metanoia [66] shows that charisma touches an existential sphere of experience and meaning of charismatic leaders [67]. Charisma can be interpreted as a subjective "boundary experience", because in this experience, individuals take on "a re- 
ligious worldview" without having to understand the process as a religious experience [68]. The experience of charisma can be seen as a religious experience, in the phenomenological sense, even when the contents of the mission are manifested externally as secular, political, or social action orientations $[67,68]$.

\section{Conclusions}

As previously mentioned, this article aimed to analyze how stigma, as a social relationship, in the context of a pandemic threat such as COVID-19 can, in some situations, structure the charismatic social relationship. Stigma, when considered as a mark of something extraordinary - a "grace from God" — that enhances the affirmation of the social status and symbolic power of social actors characterized as ill-healthy, tends to significantly transform the labeling, stereotyping, cognitive separation, and discrimination that normally attend stigma, reinforcing the charismatic legitimacy of the leader and inspiring the admiration, trust, and belief of their followers.

It was found that in the news selected and highlighted by several Portuguese media about the actions and messages developed by President Trump as part of the recovery process from an infection by SARS-CoV-2, a narrative was given visibility that can be considered as reinforcing the legitimization of the President's condition as the supreme leader of the American nation. In this narrative, moral vocabularies [69] were produced that could express to followers the belief in President Trump, who overcame the COVID-19 disease, and in his superiority and natural aptitude to lead, to govern; a fact potentially reinforced by the President being perhaps so charismatic as to let the audience think a very serious illness can be healed by the force of the Nation praying for the recovery of its own President. Charismatic authority and legitimacy depend on the ability to simultaneously convince followers that the leader has extraordinary powers and that the faith voluntarily invested by followers in the chief does not fade [69]. The foundations of the "inspirational" request for obedience are centered on the motto "obey me because I can transform your life" [69] (p. 59).

In a charismatic social relationship, stigma, when viewed as the mark of something extraordinary, may enhance the claims that individuals and dominant groups make about themselves and that they want all others to accept [69]; it may reinforce the admiration, trust, and belief in the charismatic leader by supporters and followers.

Stigmas can be considered symbolic maps revealing the political, social, and cultural structures that give them meaning and sense, which are implicated in multiple regimes of regulation [59]. A positive conception of stigma associated with illness can promote the blurring of the moral boundaries that support the process of categorization and labeling of illnesses perceived as indecent, shameful, impure, polluting, and dirty [59]. Other challenges may arise, such as discussion on the implications of the positive and negative components of stigma and the risk of stigmatization. Researchers and other agents, namely politicians, must reflect on the challenges associated with a perspective of "de-normalization" of stigma [59] and with stigmatization as a prevention and healthpromotion strategy $[21,70]$.

Author Contributions: Conceptualization, C.M.F. and S.S.; methodology, C.M.F. and S.S.; formal analysis, C.M.F. and S.S.; investigation, C.M.F. and S.S.; writing-original draft preparation, C.M.F. and S.S.; writing - review and editing, C.M.F. and S.S. All authors have read and agreed to the published version of the manuscript.

Funding: This work is financed by national funds through FCT-Foundation for Science and Technology, I.P., within the scope of the project «UIDB / 04647/2020» of CICS.NOVA—Centro Interdisciplinar de Ciências Sociais da Universidade Nova de Lisboa.

Institutional Review Board Statement: Not applicable.

Informed Consent Statement: Not applicable. 
Acknowledgments: The authors would like to thank the editor and reviewers for their comments and suggestions.

Conflicts of Interest: The authors declare no conflict of interest.

\section{References}

1. Baccini, L.; Brodeur, A.; Weymouth, S. The COVID-19 pandemic and the 2020 US presidential election. J. Popul. Econ. 2021, 34, 739-767. [CrossRef] [PubMed]

2. Sandre, I. Charisma. In Dictionary of Politics; Bobbio, N., Matteucci, N., Pasquino, G., Eds.; University of Brasília Press: Brasília, Brazil, 1998.

3. Weber, M. Types of domination. In Teorias Sociológicas. Os Fundadores e os Clássicos [Sociological Theories. The Founders and the Classics]; Cruz, M.B., Ed.; Calouste Gulbenkian Foundation: Lisboa, Portugal, 1989.

4. Lepsius, M. Le modèle de la domination charismatique et son application possible au "Führerstaat" d'Adolf Hitler [The model of charismatic domination and its possible application to Adolf Hitler's "Führerstaat"]. Trivium 2016, 23, 1-24.

5. $\quad$ Parkin, F. Max Weber; Celta Editora: Oeiras, Portugal, 1996.

6. Goffman, E. Stigma: Notes on the Management of Spoiled Identity, 4th ed.; Editora Guanabara: Rio de Janeiro, Brazil, 1988.

7. Link, B.; Phelan, J.C. Conceptualizing Stigma. Annu. Rev. Sociol. 2001, 27, 363-385. [CrossRef]

8. Ferreira, C.M.; Serpa, S.; Ferraz, J. Pestis: The Collective Challenges of Epidemics. Acad. J. Interdiscip. Stud. 2021, 10, 1. [CrossRef]

9. Villa, S.; Jaramillo, E.; Mangioni, D.; Bandera, A.; Gori, A.; Raviglione, M.C. Stigma at the time of the COVID-19 pandemic. Clin. Microbiol. Infect. 2020, 26, 1450-1452. [CrossRef]

10. Goniewicz, K.; Khorram-Manesh, A. Maintaining Social Distancing during the COVID-19 Outbreak. Soc. Sci. 2021, 10, 14. [CrossRef]

11. Qin, X.; Song, L. Addressing stigma in the context of the coronavirus disease 2019 (COVID-19) outbreak: A socio-ecological approach. Infect. Control. Hosp. Epidemiol. 2021, 1-2. [CrossRef] [PubMed]

12. Paleari, F.G.; Pivetti, M.; Galati, D.; Fincham, F.D. Hedonic and eudaimonic well-being during the COVID-19 lockdown in Italy: The role of stigma and appraisals. Br. J. Health Psychol. 2021, 26, 657-678. [CrossRef]

13. Budhwani, H.; Sun, R. Creating COVID-19 Stigma by Referencing the Novel Coronavirus as the "Chinese virus" on Twitter: Quantitative Analysis of Social Media Data. J. Med. Internet Res. 2020, 22, e19301. [CrossRef]

14. Srivastava, V.K. Anatomy of Stigma: Understanding the Case of COVID-19. Soc. Chang. 2020, 50, 385-398. [CrossRef]

15. Bhanot, D.; Singh, T.; Verma, S.K.; Sharad, S. Stigma and Discrimination during COVID-19 Pandemic. Front. Public Health 2021, 8 , 577018. [CrossRef]

16. Watkins, D.V.; Clevenger, A.D. US Political Leadership and Crisis Communication during COVID-19. Cogent Soc. Sci. 2021, 7, 1901365. [CrossRef]

17. WHO. Social Stigma Associated with COVID-19: A Guide to Preventing and Addressing Social Stigma. 2020. Available online: https: //www.who.int/docs/default-source/epi-win/stigma/covid19-stigma-guide.pdf?sfvrsn=48f6ac1_2\&download=true (accessed on 22 July 2021).

18. Major, B.; O’Brien, L.T. The Social Psychology of Stigma. Annu. Rev. Psychol. 2005, 56, 393-421. [CrossRef]

19. Herzlich, C. Modern medicine and the search for meaning: The disease as a social signifier. In The Meaning of Evil. Anthropology, History, Sociology of Disease, 3rd ed.; Augé, M., Herzlich, C., Eds.; Éditions des Archives Contemporaines: Paris, France, 1991.

20. Deacon, H. Towards a sustainable theory of health-related stigma: Lessons from the HIV/AIDS literature. J. Community Appl. Soc. Psychol. 2006, 16, 418-425. [CrossRef]

21. Désy, M.; Filiatrault, F. Ethical Dimension of Stigma in Public Health. A Thinking Aid Tool; Institut National de Santé Publique du Québec: Quebec City, QC, Canada, 2013.

22. Becker, G.; Arnold, R. Stigma as a social and culture construct. In The Dilemma of Difference; Ainlay, S., Becker, G., Col-man, L., Eds.; Plenum: New York, NY, USA, 1986; pp. 39-76.

23. Siqueira, R.; Cardoso, H. The concept of Stigma as a social process: A theoretical approach from the North American literature. Imagonautas 2011, 2, 92-113.

24. Fabre, G. Epidemics and Contagions. The Imagination of Evil in the West; PUF: Paris, France, 1998.

25. Ferreira, C.M.; Serpa, S. Contagions: Domains, Challenges and Health Devices. Acad. J. Interdiscip. Stud. 2020, 9, 1. [CrossRef]

26. Bologna, L.; Stamidis, K.V.; Paige, S.; Solomon, R.; Bisrat, F.; Kisanga, A.; Usman, S.; Arale, A. Why Communities Should Be the Focus to Reduce Stigma Attached to COVID-19. Am. J. Trop. Med. Hyg. 2021, 104, 39-44. [CrossRef] [PubMed]

27. Amir, K. COVID-19-related stigma in COVID-19 survivors in Kampala, Uganda: A qualitative study. Preprints 2021. [CrossRef]

28. Turner-Musa, J.; Ajayi, O.; Kemp, L. Examining Social Determinants of Health, Stigma, and COVID-19 Disparities. Healthcare 2020, 8, 168. [CrossRef] [PubMed]

29. Borges, T.P.; Schulz, R.D.S.; de Magalhães, J.B.; Campos, L.M.; dos Anjos, K.F.; Rosa, D.D.O.S. Stigmas related to COVID-19 and their prevention. Physis J. Collect. Health 2021, 31. [CrossRef]

30. Abdelhafiz, A.S.; Alorabi, M. Social Stigma: The Hidden Threat of COVID-19. Front. Public Health 2020, 8, 429. [CrossRef]

31. Muhidin, S.; Vizheh, M.; Moghadam, Z.B. Anticipating COVID-19-related stigma in survivors and health-care workers: Lessons from previous infectious diseases outbreaks-An integrative literature review. Psychiatry Clin. Neurosci. 2020, 74, 617-618. [CrossRef] [PubMed] 
32. Peprah, P.; Gyasi, R.M. Stigma and COVID-19 crisis: A wake-up call. Int. J. Health Plan. Manag. 2020, 36, 215-218. [CrossRef]

33. Chopra, K.; Arora, V. COVID-19 and social stigma: Role of scientific community. Indian J. Tuberc. 2020, 67, 284-285. [CrossRef]

34. Nuckchady, D.C. Stigma Linked to COVID-19. Int. Neuropsychiatr. Dis. J. 2021, 29-38. [CrossRef]

35. Choi, S. "People look at me like I AM the virus": Fear, stigma, and discrimination during the COVID-19 pandemic. Qual. Soc. Work. Res. Pract. 2020, 20, 233-239. [CrossRef]

36. Joshi, B.; Swarnakar, P. Staying away, staying alive: Exploring risk and stigma of COVID-19 in the context of beliefs, actors and hierarchies in India. Curr. Sociol. 2021. [CrossRef]

37. van Daalen, K.R.; Cobain, M.; Franco, O.H.; Chowdhury, R. Stigma: The social virus spreading faster than COVID-19. J. Epidemiol. Community Health 2021, 75, 313-314. [CrossRef]

38. Roelen, K.; Ackley, C.; Boyce, P.; Farina, N.; Ripoll, S. COVID-19 in LMICs: The Need to Place Stigma Front and Centre to Its Response. Eur. J. Dev. Res. 2020, 32, 1592-1612. [CrossRef] [PubMed]

39. Lohiniva, A.-L.; Dub, T.; Hagberg, L.; Nohynek, H. Learning about COVID-19-related stigma, quarantine and isolation experiences in Finland. PLoS ONE 2021, 16, e0247962. [CrossRef]

40. Schubert, M.; Ludwig, J.; Freiberg, A.; Hahne, T.; Starke, K.R.; Girbig, M.; Faller, G.; Apfelbacher, C.; Knesebeck, O.V.D.; Seidler, A. Stigmatization from Work-Related COVID-19 Exposure: A Systematic Review with Meta-Analysis. Int. J. Environ. Res. Public Health 2021, 18, 6183. [CrossRef] [PubMed]

41. UNICEF. Social Stigma Associated with the Coronavirus Disease (COVID-19). Available online: https://www.unicef.org/media/ 65931/ file/Social\%20stigma\%20associated\%20with\%20the\%20coronavirus\%20disease\%202019\%20(COVID-19).pdf (accessed on 24 February 2020).

42. Jesus, T.; Bhattacharjya, S.; Papadimitriou, C.; Bogdanova, Y.; Bentley, J.; Arango-Lasprilla, J.; Kamalakannan, S.; The Refugee Empowerment Task Force, International Networking Group of the American Congress of Rehabilitation Medicine. LockdownRelated Disparities Experienced by People with Disabilities during the First Wave of the COVID-19 Pandemic: Scoping Review with Thematic Analysis. Int. J. Environ. Res. Public Health 2021, 18, 6178. [CrossRef] [PubMed]

43. Das, M. Social Construction of Stigma and Its Implications-Observations from COVID-19. SSRN Electron. J. 2020. Available online: https:/ / ssrn.com/abstract=3599764 (accessed on 12 July 2021). [CrossRef]

44. WHO. Guidelines Aimed at Reducing the Stigma Associated with COVID-19 Towards Health Professionals and Their Families. Available online: https://www.afro.who.int/sites/default/files/Covid-19/Techinical\%20documents/Orienta\%C3\%A7\%C3\%B5 es $\%$ 20destinadas $\% 20$ a $\%$ reduzir $\% 20$ o $\% 20$ estigma $\% 20$ associado $\% 20 \%$ C3\%A0\%20COVID-19\%20em $\% 20$ rela $\%$ C3 $\%$ A7 $\%$ C3

\%A3o $\% 20$ a $\% 20$ profissionais $\% 20 \mathrm{de} \% 20$ sa $\%$ C3\%BAde $\% 20 \mathrm{e} \% 20$ suas $\% 20$ fam $\%$ C3\%ADlias.pdf (accessed on 12 July 2021 ).

45. Gomes, R. Body and risks. In Words beyond the Pandemic: One Hundred Sides of a Crisis; Reis, J., Ed.; Centre for Social Studies, University of Coimbra: Coimbra, Portugal, 2020.

46. Sotgiu, G.; Carta, G.; Suelzu, L.; Carta, D.; Migliori, G.B. How to demystify COVID-19 and reduce social stigma. Int. J. Tuberc. Lung Dis. 2020, 24, 640-642. [CrossRef]

47. Etika, A.N.; Yunalia, E.M.; Lutfi, E.I.; Sulisyawati, W. Impact of Stigma in COVID-19 Patient: A Litteratur Review. J. Qual. Public Health 2020, 4, 161-164. [CrossRef]

48. Spink, P. Analysis of public domain documents. In Discursive Practices and Production of Meaning in the Everyday Life. TheoreticalMethodological Approaches; Spink, M.J., Ed.; Centro Edelstein de Pesquisas Sociais: Rio de Janeiro, Brazil, 2013 ; pp. 100-126.

49. Macedo, I.; Cabecinhas, R. Social representations, migrations and media: Reflections on the role of film literacy in the promotion of interculturality. In On Communication and Culture: I PhD Student Conference in Communication Sciences and Cultural Studies; Pinto-Coelho, Z., Fidalgo, J., Eds.; Universidade do Minho-Centro de Estudos de Comunicação e Sociedade: Braga, Portugal, 2012.

50. Van Dijk, T. News as Discourse; Laurance Erlbaum: Hillsdale, NJ, USA, 1988.

51. Carvalho, A. Methodological options in discourse analysis-Instruments, assumptions and implications. Comun. Soc. 2000, 2, 143-156. [CrossRef]

52. Herrick, C. Geographic charisma and the potential energy of Ebola. Sociol. Health Illn. 2019, 41, 1488-1502. [CrossRef]

53. Joosse, P. Countering Trump: Toward a Theory of Charismatic Counter-Roles. Soc. Forces 2018, 97, 921-944. [CrossRef]

54. Tanne, J.H. COVID-19: Trump returns to White House amid confusion over his illness and treatment. BMJ 2020, 371, m3897. [CrossRef] [PubMed]

55. Laplantine, F. Anthropology of the Disease; Petite Bibliothèque Payot: Paris, France, 1986.

56. Canguilhem, G. The Normal and the Pathological; Presses Universitaires de France: Paris, France, 2013.

57. Herzlich, C. Health and Sickness. Analysis of a Social Representation, 4th ed.; Éditions EHESS: Paris, France, 1969.

58. Carapinheiro, G. Health in the context of sociology. Sociol.—Probl. Práticas 1986, 1, 9-22.

59. Carapinheiro, G. Health and illness: A critical health sociology program. Sociol. Line Rev. Assoc. Port. Sociol. 2011, 3, 57-71.

60. Moore, S.; Myerhoff, B. Secular Ritual; Van Gorcum: Assen/Amsterdam, The Netherlands, 1977.

61. Brown, G. Theorizing ritual as performance: Explorations of ritual indeterminacy. J. Ritual Stud. 2003, 17, 3-18. Available online: https:/ / www.jstor.org/stable/44368641 (accessed on 27 July 2021).

62. Bourdieu, P. Rites as acts of institution. Actes Recherche Sci. Soc. 1982, 43, 58-63. Available online: https://www.persee.fr/doc/ arss_0335-5322_1982_num_43_1_2159 (accessed on 4 August 2021).

63. Good, B.J. The heart of what's the matter the semantics of illness in Iran. Cult. Med. Psychiatry 1977, 1, 25-58. [CrossRef] 
64. Massé, R. Culture and Public Health. The Contributions of Anthropology to Health Prevention and Promotion; Gaëtan Morin: Montréal, QC, Canada, 1995.

65. Bourdieu, P. About on the State. Course at the Collège de France (1989-1992); Edições 70: Lisboa, Portugal, 2014.

66. Weber, M. (Ed.) Economy and Society; Editora da UnB: Brasília: Brazil, 1999.

67. Bach, M. Charism and rationalism in Max Weber's sociology. Rev. Sociol. Antropol. 2011, 1, 51-70. [CrossRef]

68. Schütz, A.; Luckmann, T. The Structures of the Life-World; Northwestern University Press: Evanston, IL, USA, 1989.

69. Parkin, F. Max Weber, 2nd ed.; Celta Editora: Oeiras, Portugal, 2000.

70. Weiss, M.G.; Ramakrishna, J.; Somma, D. Health-related stigma: Rethinking concepts and interventions 1. Psychol. Health Med. 2006, 11, 277-287. [CrossRef] 